\title{
Navigating Power and Claiming Justice: Tenant Experiences at Saskatchewan's Housing Law Tribunal $^{1}$
}

\section{Sarah Buhler \\ Rachel Tang*}

This article discusses a qualitative interview project where twenty tenants shared their experiences about having hearings at the Office of Residential Tenancies [the ORT], Saskatchewan's housing law tribunal. The interviews provide insights into housing problems faced by tenants, their experiences with self-representation at the ORT, and their reflections about the outcomes of their cases. We analyze how tenants prepared for their hearings, their experiences of the hearing process, and their perceptions of fairness throughout the process. We then discuss participants' assessments of whether they received "justice" at the ORT. The interviews illuminate the ways that the same patterns of power and inequality that produce housing problems in the first place persist but are also occasionally interrupted and exposed in the housing tribunal process. They show also that tenants use the ORT to make important claims about justice and to resist landlord power in the face of larger patterns of inequality and exploitation.

Cet article porte sur un projet d'entrevues qualitatives dans le cadre duquel vingt locataires ont partagé leurs expériences au sujet de leur audience devant l'Office of Residential Tenancies [ORT] (bureau de location à usage d'habitation), le tribunal du logement de la Saskatchewan. Les entrevues donnent un aperçu des problèmes de logement auxquels les locataires font face, de l'expérience qu'ils ont vécue lorsqu'ils se sont représentés eux-mêmes devant l'ORT, et de leurs réflexions au sujet de l'issue de leur affaire. Nous analysons la façon dont les locataires se sont préparés en vue de leur audience, l'expérience qu'ils ont vécue durant l'audience, et leurs perceptions quant à l'équité du processus. Nous abordons ensuite les évaluations des participants quant à la mesure dans laquelle ils ont obtenu justice devant l'ORT. Les entrevues permettent de constater que les mêmes inégalités et déséquilibres de pouvoir qui sont à l'origine des problèmes de logement persistent, mais peuvent aussi être interrompus et exposés à l'occasion au cours du processus du tribunal du logement. Elles montrent également que les locataires se tournent vers l'ORT pour formuler d'importantes revendications liées à la justice et pour contester le pouvoir des propriétaires malgré les inégalités et l'exploitation croissantes observées.

$1 \quad$ Funding for this study was provided by the Law Foundation of Saskatchewan. We acknowledge the amazing help of research assistants Davida Bentham, Catriona Kaiser-Derrick, and Jorgina Sunn.

* Sarah Buhler is an Associate Professor at the University of Saskatchewan College of Law. Rachel Tang is a Qualitative Research Manager at the Social Sciences Research Laboratories (SSRL) at the University of Saskatchewan 


\section{INTRODUCTION}

In many Canadian jurisdictions, specialized housing law tribunals adjudicate disputes between landlords and tenants. These administrative tribunals make decisions that matter deeply to those affected by them, including eviction orders. After all, safe and secure housing is fundamental to human wellbeing and is a key determinant of physical and psychological health. ${ }^{2}$ As Lorna Fox O'Mahony has stated, “...homes matter. They matter to the people who have them, and to those who do not; they matter to those who have lost a home through displacement or dispossession." 3 However, despite the significant role that housing law tribunals play in adjudicating issues relating to housing, there is very little empirical research in Canada about the work of these tribunals or the experiences of people who appear before them. ${ }^{4}$

This project responds to this research gap through qualitative interviews with 20 low income Saskatoon tenants who navigated hearings before Saskatchewan's housing law tribunal, known as the Office of Residential Tenancies [ORT]. The interviews, which were conducted in 2017, provide insights into housing problems faced by tenants, their experiences with self-representation at the ORT, and their reflections about the outcomes of their cases. In so doing, this research makes a contribution to the growing body of empirical research that focuses on people's experiences with law and the justice system, ${ }^{5}$ as well as the literature on people's housing experiences more generally. ${ }^{6}$

In this article, we first provide contextual and theoretical background to our project. We argue that the landlord-tenant relationship is characterized by an inherent power imbalance and that larger systemic and structural forces conspire to produce many of the individual housing law problems faced by tenants. Further, we assert that housing law regimes often fail to acknowledge these wider inequities. A brief discussion of our methodology precedes an examination of the interviews via qualitative analysis. We

2 See for example: Wellesley Institute, "Housing and Health: Examining the Links" (2012), online (pdf): Wellesley Institute $\leq \mathrm{https}: / / \mathrm{www}$.wellesleyinstitute.com/wp-content/uploads/2012/10/Housing-and-Health-Examining-theLinks.pdf $>$; Toba Bryant, "The Current State of Housing in Canada as a Social Determinant of Health" (2003), online: Policy Options <http://irpp.org/wp-content/uploads/assets/po/bank-mergers/bryant.pdf z; Allyson E Gold, "No Home For Justice: How Eviction Perpetuates Health Inequity Among Low-Income and Minority Tenants" (2014) 24 Geo J on Poverty Law Pol'y 59.

3 Lorna Fox O’Mahony, "The Meaning of Home: from Theory to Practice" (2013) 5 Int J Law in the Built Environment 16 at 158 .

4 Two exceptions are: Emily Paradis' study of duty counsel at the Ontario Landlord and Tenant Board (Emily Paradis, "Access to Justice: the Case for Ontario Tenants. Final Report of the Tenant Duty Counsel Review" (2016), online: Advocacy Centre for Tenants Ontario $<\mathrm{https} / / \mathrm{www}$.acto.ca/production/wpcontent/uploads/2017/07/TDCP_Report_2016.pdf>; and Leora Smith, examples of empirical work in this area include: Emily Paradis \& Leora Smith, “The Gendered Impact of Illegal Act Eviction Laws" (2017) 52 Harv CR-CLL Rev 537.

5 See Paradis, ibid for an example of an empirical study that considers the experiences of tenants at Ontario's housing law tribunal. Canadian studies that focus on the justice system experiences of members of marginalized communities include: Janet E Mosher, "Lessons in Access to Justice: Racialized Youths and Ontario's Safe Schools" (2008) 46:4 Osgoode Hall LJ 807; Amanda Dodge, "Access to Justice Metrics Informed by the Voices of Marginalized Community Members: Themes, Definitions and Recommendations Arising from Community Consultations" (March 2013), online: Canadian Bar Association <www.cba.org/CBA/cle/PDF/JUST13_Paper_Dodge.pdf>; and Mary Stratton, "Access to Justice? The View from the Street" (November/December 2010) 35:2 at 7, online (pdf): LawNow $<$ www.lawnow.org/wp-content/uploads/2012/08/LawNow35-2.pdf $>$.

6 See for example: K Milaney et al, "Understanding Mothers Experiencing Homelessness: A Gendered Approach to Finding Solutions to Family Homelessness" (Toronto: Canadian Observatory on Homelessness Press: 2017); Isolde Daiski et al, "Homelessness in the Suburbs: Engulfment in the Grotto of Poverty" (2012) 6 Studies in Social Justice 103; Sarah Benbow et al, "Spaces of Exclusion: Safety, Stigma, and Surveillance of Mothers Experiencing Homelessness" (2019) 51:3 Can J of Nursing Research 202. 
introduce the tenants, and discuss the importance of "home" in their narratives. With this background in place, we discuss the nature of the claims that brought the tenants to the ORT. We analyze how tenants prepared for their hearings, their experiences of the hearing process, and their perceptions of fairness throughout the process. Finally we turn to outcomes and participants' assessments of whether they received "justice" at the ORT. The interviews illuminate the ways that the same patterns of power and inequality that produce housing problems in the first place persist but are also occasionally interrupted and exposed in the housing tribunal process. They show also that tenants use the ORT to make important claims about justice and to resist landlord power in the face of larger patterns of inequality and exploitation.

\section{CONTEXTS AND BACKGROUND}

\section{A. Housing in Saskatoon}

Saskatoon has for years experienced a crisis in housing affordability and availability. ${ }^{7}$ As one of the participants in our study explained: "Housing here has been twice as hard as from living here like seven years ago. It is more complicated to get through things." "The city has faced low vacancy rates and high rents, with a growing number of people experiencing "core housing need", meaning that "housing falls below at least one of the adequacy, affordability, or suitability standards and [a household] would have to spend $30 \%$ or more of its total before-tax income to pay the median rent of alternative local housing that is acceptable". ${ }^{9}$ Affordable housing units are limited ${ }^{10}$ and social assistance rates often do not cover the cost of rent. Many people who rely on social assistance have to choose between paying rent and being able to afford food or other basic necessities. ${ }^{11}$ In addition to affordability, there are ongoing issues relating to the safety and habitability of rental housing in the city, especially rental housing that is accessible to low-income residents. Many rental units are characterized by problems including mold, structural damage, broken doors and windows, and inadequate heating systems. ${ }^{12}$ A recent report by the Saskatchewan Human Rights Commission expressed concern about inadequate heating, high rent, prevalence of pests, and discrimination faced by many renters. ${ }^{13}$

7 See Canadian Centre for Policy Alternatives, "Rental Wages in Canada", online:

$<$ https://www.policyalternatives.ca/rentalwages $>$ (interactive online map showing unafforability of rental accommodations in Saskatoon and other Canadian cities). See also David Macdonald, "Unaccommodating: Rental Housing Wages in Canada" (Ottawa: Canadian Centre for Policy Alternatives, 2019), online (pdf): https://www.policyalternatives.ca/sites/default/files/uploads/publications/National\%20Office/2019/07/Unaccommodatin g\%20-\%20Rental\%20Wage\%20in\%20Canada.pdf at 12. See also M Lemstra \& W Sharpe, "Housing Disparity" in Mark Lemstra \& Cory Neudorf, eds, Health Disparity in Saskatoon: Analysis to Intervention (Saskatoon: Saskatoon Health Region, 2008) at 286; see also Alan Anderson, Home in the City: Urban Aboriginal Housing and Living Conditions (Toronto: University of Toronto Press, 2013) at 34 and 195.

$8 \quad$ Interview 7 (on file with authors).

9 Saskatoon Housing Initiatives Partnership, “Core Housing Need” online: https://www.shipweb.ca/test.

10 Saskatchewan Human Rights Commission, Access and Equality for Renters in Receipt of Public Assistance: A Report to Stakeholders (Saskatoon: Saskatchewan Human Rights Commission, 2018) at 13.

11 Ibid at 7. See also Anderson, supra note 7 at 104.

12 Anderson, supra note 7 at 255.

13 Supra note 10 at 12, 20. See also Ryan Jimmy \& Isobel Findlay, "YXE Connects 2015: A Research Report" (Saskatoon: Community-University Institute for Social Research, 2015) at 12. 


\section{B. Power, Exploitation, and the Landlord-tenant Relationship}

Geographer Katherine Brickell has asserted that "the intimate and personal spaces of home - and their loss - are closely bound up with, rather than separate from, wider power relations." ${ }^{14}$ Central here is the landlord-tenant relationship, which is characterized by an inherent power imbalance. As Kathryn Sabbeth points out in her analysis of the American housing law context, "[t]he tenant's access to a basic necessity of life hinges on the landlord's willingness to provide it. The landlord controls the tenant's ability to access her home and reside there in peace and security, and this gives the landlord a special physical and psychological power over the tenant and all other occupants." 15 Similarly, Maggie Reed writes, "as the shortage of affordable housing becomes more acute...those who control the resources become increasingly powerful and those who lack them become correspondingly more vulnerable." 16 Some landlords exploit this power directly in their relationships with tenants through sexual harassment and violation of tenants' privacy; threatening evictions, and locking tenants out of their homes. In his influential study of evictions in the City of Milwaukee, sociologist Matthew Desmond noted that many landlords "keep a basis for eviction in their back pockets" and use this threat coercively. ${ }^{17}$

Desmond argues that the wider dynamics of the rental housing market and the legal regimes regulating this market also enable the exploitation of low-income tenants on a more systemic level. ${ }^{18}$ For example, Desmond's research showed that in the American context, it is often cheaper for landlords to evict lowincome tenants rather than attend to necessary repairs. ${ }^{19}$ Ezra Rosser, writing about Desmond's work, explains that "landlords are able to derive considerable profit from low-income housing and...they have tremendously more power than their tenants. Landlords enjoy the privilege of rules that privilege their position vis-a-vis their tenants - benefits that are made all the more powerful because these rules are treated by landlords, tenants, and courts alike as the natural way the landlord-tenant relationship should be governed." 20 As Desmond concludes, "It comes down to a system that provides landlords with a lot of power over low-income tenants." 21

Desmond's analysis resonates in the Canadian context. ${ }^{22}$ Exploitation of tenants is made possible by a profit-driven rental housing market ${ }^{23}$, inadequate social assistance and social housing programs, and a legal framework that naturalizes the ability of landlords to evict vulnerable tenants (for example, for nonpayment of rent). A study by the British Columbia Rental Housing Task Force reported "difficult and

14 Katherine Brickell, “'Mapping' and 'Doing' Critical Geographies of Home” (2012) 36 Progress in Human Geography 225 at 230.

15 Kathryn A Sabbeth, "Housing Defense as the New Gideon" (2018) 41 Harv JL \& Gender 2 at 46.

16 Maggie E Reed et al, "There's No Place Like Home: Sexual Harassment of Low Income Women in Housing” (2005) 11 Psychol Pub Pol'y \& L 439 at 440.

17 Matthew Desmond, Evicted: Poverty and Profit in the American City (New York: Crown Publishers, 2016) at 129.

18 Ibid at 305-306.

19 Ibid at 75.

20 Ezra Rosser, "Exploiting the Poor: Housing, Markets, and Vulnerability" (2016) 126 Yale LJ 458 at 467.

21 Desmond quoted in Kevin Nance, "Matthew Desmond's 'Evicted' details costs of evictions on Milwaukee's poor", Chicago Tribune (10 March 2016), online: <https://www.chicagotribune.com/lifestyles/books/ct-prj-evicted-matthewdesmond-20160310-story.html>. American studies show that: the Hidden those evicted are typically poor, women and minorities: Chester Hartman \& David Robinson, "Evictions Housing Problem" (2003) 14:4 Housing Policy Debate 461 at 467.

22 Anna Lund, "Book Review of Evicted: Poverty and Profit in the American City" by Matthew Desmond, (2016) 54 Alta L Rev 233.

23 See Margot Young, "Charter Eviction: Litigating out of House and Home” (2015) 24 J of Law \& Soc Pol'y 46 at 51: Young notes that Canada has proportionately the largest private-sector housing market of any western nation. 
abusive rental housing providers" as one of the top complaints of renters across the province. ${ }^{24}$ Emily Paradis similarly described "discrimination against and exploitation of the most vulnerable groups" in her study of the duty counsel program at the Ontario Landlord and Tenant Board. ${ }^{25}$ In her overview of the conditions of precarious housing in Canada, Margot Young writes: "[y]ounger women will trade sex for shelter. Families live in spaces that are too small, with mould or infestations. Households in core housing need are likely to compromise full and dignified involvement in Canadian society in exchange for maintaining some form of housing. And some, simply, go homeless."26

Embedded in the dynamics described above are intersecting systemic forces including colonialism, racism, and sexism. In her study of the Tenant Duty Counsel program in Ontario, Emily Paradis noted that "[i]t is impossible to ignore the extent to which [housing law troubles] are structurally determined. For most tenants, coming before the LTB [the Landlord and Tenant Board] is the product of multiple, intersecting inequities, injustices, and experiences of discrimination and marginalization." 27 Paradis noted those most likely to find themselves in precarious housing situations included "people with disabilities, Indigenous and racialized persons, lone mothers, immigrants, people on social assistance." 28 Similarly, a study by the Saskatchewan Human Rights Commission noted that racism, sexism and discrimination all functioned to produce and impact the housing experiences of tenants. ${ }^{29}$

Indigenous scholars including Jesse Thistle and Gabrielle Weasel Head have made the point that Indigenous experiences of homelessness and housing are connected to larger colonial patterns of dispossession. ${ }^{30}$ This is especially the case in cities like Saskatoon, where Indigenous people are almost three times more likely than non-Indigenous people to be living in homes requiring major repairs. ${ }^{31}$ Julie Christensen explains: "Colonialism has, in myriad cross-generational ways, disrupted Indigenous homemaking practices by displacing Indigenous people from their ancestral lands, separating children from their families, and implementing exclusionary socio-spatial structures". ${ }^{32}$

Sexism and misogyny also operate in this context. As Margot Young has stated, "[w]ithout doubt, the disadvantages and harms of inadequate housing are, like much else in society, gendered." ${ }^{33}$ This observation is echoed by American research that examines the particular problems that women face in

24 British Columbia Rental Housing Task Force, "Rental Housing Review: Recommendations and Findings" (2018) online: $<$ https://engage.gov.bc.ca/app/uploads/sites/121/2018/12/RHTF-Recommendations-and-WWH-

Report_Dec2018_FINAL.pdf >at 33.

25 Supra note 4 at $8 \overline{2}$.

26 Supra note 23 at 51.

27 Supra note 4 at 82.

28 Ibid.

29 Supra note 10 at 22-23, 11-12.

30 Jesse Thistle, "Definition of Indigenous Homelessness in Canada" (Toronto: Canadian Observatory on Homelessness, 2017); Gabrielle Weasel Head \& Yale D Belanger, “'All We Need is Our Land': Exploring Southern Alberta Urban Aboriginal Homelessness" (Toronto: The Homeless Hub, 2014).

31 Anderson, supra note 7 at 74 . As Cindy Holmes and Sarah Hunt write, we too easily forget "the city as a site of dispossession." Cindy Holmes \& Sarah Hunt, "Violence, Colonialism, and Space: Towards a Decolonizing Dialogue" (2014) 14 ACME: An International E-Journal for Critical Geographies 539 at 550.

32 Julie Christensen, "No Home in a Homeland: Indigenous Peoples and Homelessness in the Canadian North" (Vancouver: UBC Press, 2017) at 34

33 Supra note 23 at 53; West Coast LEAF Briefing Note, "Amending the Residential Tenancy Act to Protect Victims of Domestic Violence" (2014), online: <http:/www.westcoastleaf.org/wp-content/uploads/2014/11/2014-04-20SUBMISSION-Amending-the-RTA-to-Protect-Victims-of-Domestic-Violence.pdf>; Jonette Watson Hamilton, "Reforming Residential Tenancy Law for Victims of Domestic Violence" (2019) 8 Ann Rev Interdisciplinary Justice Research 245. 
rental housing situations. ${ }^{34} \mathrm{An}$ intersectional lens shows that sexism and racism function together to compound the risks faced by particular groups, such as Black women in the United States or Indigenous women in Canada. In the American context, Sabbeth has noted that eviction and housing problems disproportionately affect Black women. ${ }^{35}$ Indigenous scholars have made the connection between settler colonialism, the imposition of colonial property regimes, and violence against Indigenous women and families. ${ }^{36}$ For example, Cindy Holmes and Sarah Hunt argue that colonial ideas work to "justify spatialized practices of containment, surveillance, control, and erasure" over Indigenous homes. ${ }^{37}$

\section{Housing Law Processes in Context}

Sameer Ashar and Annie Lai argue that "legal disputes take place in the context of a larger political field"38: it is within the larger political, economic, and social context described above that the ORT adjudicates disputes between landlords and tenants. The ORT was created by, and operates pursuant to, the Residential Tenancies Act ("the Act"). ${ }^{39}$ The Act sets out the rights and responsibilities of landlords and tenants, including rules around payment of rent, evictions, maintenance obligations of landlords, tenants' right of privacy, and more. According to the Government of Saskatchewan, the Act and its accompanying Regulations "balance...the needs of tenants for safe, secure, and habitable living accommodations, and the needs of landlords to conduct a viable business and protect their property investment" ${ }^{40}$ The law permits landlords to evict tenants for a wide variety of reasons, including nonpayment of rent, but requires that ORT hearing officers only grant the order of possession if they are satisfied that it would be "just and equitable in the circumstances" to do so. ${ }^{41}$ However, a review of Court decisions indicates that non-payment or late payment of rent are almost always grounds for eviction. ${ }^{42}$ Our interviews also suggest that non-payment or late payment of rent are close to being guarantees that an eviction will be ordered. According to the Act, landlords are generally not permitted to enter rental units without notice or permission; and landlords have an obligation to maintain the habitability of the rental unit. ${ }^{43}$ However, as we will describe, our interviews point to the fact that some landlords ignore these requirements with impunity.

The ORT receives over 8,000 applications per year. ${ }^{44}$ However, we note that this statistic is likely an underrepresentation of the actual number of housing-related legal problems: many tenants are reluctant to file complaints about housing conditions or landlords for reasons including fear of reprisal and a lack of

34 See Sabbeth, supra note 15 at 42; and see Smith, supra note 4.

35 Supra note 15 at 42.

36 See, e.g. Kelsey T Leonard, "The (Un)Making of Property: Gender Violence and the Legal Status of Long Island Algonquin Women" in Kim Anderson et al, eds, Keetsahnak: Our Missing and Murdered Indigenous Sisters (Edmonton: University of Alberta Press, 2018) 103; Andrea Smith, Conquest: Sexual Violence and American Indian Genocide (Durham: Duke University Press, 2005).

37 Supra note 31 at 550.

38 Sameer Ashar \& Annie Lai, “Access to Power”(2019) 148 Daedalus 82 at 83.

39 The Residential Tenancies Act, 2006, chap R-22.0001 of the Statutes of Saskatchewan, 2006, as amended, online: $<\mathrm{http}: / /$ www.qp.gov.sk.ca/documents/english/statutes/statutes/r22-0001.pdf > at s 14 .

40 See Government of Saskatchewan, "Rights and Responsibilities of Landlords and Tenants", online: $<$ https://www.saskatchewan.ca/business/housing-development-construction-and-property-management/landlords-andrental-properties/landlord-and-tenant-rights-and-responsibilities>.

$41 \quad$ Supra note 39 at s $70(6)$.

42 ORT decisions found online at $<$ https://www.canlii.org/en/sk/skort/>.

43 Supra note 391 at s49.

44 Ministry of Correcti ons and Policing; Ministry of Justice and Attorney General, “Annual Report 2017-2018”, online (pdf): <http://publications.gov.sk.ca/documents/9/107684-2017-18_Justice_Corrections_AR_web.pdf $>$ at 34. 
trust in public agencies. ${ }^{45}$ Indeed, several participants in our study described their own reluctance to engage in the ORT process, and spoke also to the reluctance of people in their community to do so. As one interviewee stated: "Because a lot of people, I do understand now, that when they have problems with the [ORT] or with the Landlords and things like that, most people will just pack up and bounce out... I don't even bother wanting to be involved with the [ORT] anymore. As soon as I get an eviction notice I'm just 'ohhhh', I'm already packing..."46

Scholars who have studied the processes of housing law courts in the United States have shown that in practice these courts often function to perpetuate power imbalances and inequities between landlords and tenants. For example, in her influential 1991 study of the Baltimore rent court, Barbara Bezdek argues that "the forum fails to provide redress for the claims of tenants with anything like the regard it accords the formal rights of landlords, which are delivered with smooth and speedy dispatch." ${ }^{47}$ Bezdek's research showed that "the operational premise of the rent court as an institution is to enforce the entitlement of the landlord to payment and possession, while it obscures the entitlement of tenants under the same governing law."48 According to Bezdek, this happens through a process of "subordination" of tenants' voices and claims within the court process. ${ }^{49}$ In a more recent American study, Kathryn Sabbeth argues that the "power differential between landlords and tenants is exacerbated in Housing Court." 50 In this way, Ashar and Lai's observation that "the legal system distributes rights and privileges based on a particular configuration of interests, favoring those who have power and burdening those who do not" 51 rings true. Our interviews show that these observations resonate in the ORT context. The interviews reveal that while landlord power is moderated or attenuated in some instances within the ORT hearing process, the process and the legal framework do not disturb underlying and overarching inequalities. We explore these themes and tensions in the discussion that follows.

\section{METHODOLOGY}

We received ethics approval for the study from the University of Saskatchewan Behavioural Ethics Board. ${ }^{52}$ The interview guide was prepared in consultation with a community-based research assistant. The community member, who had lived experience of poverty, criminalization, and housing insecurity, was able to assist with the generating of substantive interview topics and ensure that the questions were clear. This community member's involvement helped ensurethat interviews were carried out in a respectful and appropriate manner. Posters inviting interview participants were distributed to libraries and community organizations. Anyone with a recent experience at the Office of Residential Tenancies was eligible to participate. Interviews were conducted starting in March of 2017 and concluded at the end of 2017. Interviews were recorded using a digital voice recorder and were transcribed on a rolling basis by two law student research assistants, who also assisted in conducting the interviews. Interviews lasted for about 30-60 minutes and covered a range of topics relating to the tenant's housing law problem and their experience at the ORT. As the interviews were semi-structured, not all interviewees were asked exactly

45 Saskatchewan Human Rights Commission, supra note 10 at 3,14.

46 Interview 16.

47 Barbara Bezdek, "Silence in the Court: Participation and Subordination of Poor Tenants' Voices in Legal Process" (1991-1992) 20 Hofstra L Rev 533 at 533.

48 Ibid at 540.

49 Ibid at 564.

50 Sabbeth, supra note 15 at 46.

51 Supra note 38 at 83.

52 Ethics Certificate on file with authors. 
the same questions: each interview followed its own path based on the interviewee's responses. A total of 27 interviews were completed as a part of this project. However, seven interview participants had been represented by advocates or counsel. Because the experience of representation at the ORT is different than that of navigating the process without assistance, those interviews will be considered elsewhere.

Transcripts were imported into the NVivo 11 Pro for Windows software suite and coded independently by the authors in order to establish validity through inter-rater reliability. Codes (thematic categories) were generated based on a review of the literature but also iteratively as themes emerged or were reconfigured through the coding process. The coding team met on several occasions to discuss and alter the coding scheme in order to reach better statistical consensus on key themes. Over a 10-month period interviews were scanned and coded according to an agreed-upon code book. Coding Comparison queries, displays of coding stripes by user, and explore functions were all utilized in order to investigate disparities (significant or not) in coding and inform adjustments on either coder's part in order to prompt further alignment on categorical placement of data extracts.

We believe that all qualitative research about social phenomena is an interpretive process: there is no one single "truth" contained in any data set. We agree with David Altheide and John Johnson that "[a]11 theories, concepts, and findings are grounded in values and perspectives; all knowledge is contextual and partial; and other conceptual schemas and perspectives are always possible." ${ }^{" 53}$ Therefore, the themes identified here and our analysis and interpretation of what we heard in the interviews are not exhaustive: other themes and insights are always possible.

\section{THEMES AND ANALYSIS}

\section{A. The Tenants}

Of the 20 participants who represented themselves, the majority (12) identified as Indigenous women (including Metis, Cree and Inuit). This is significant given the discussion above about the intersection of gender and race in housing law problems. Two interviewees were non-Indigenous women; two were Indigenous men, and four were non-Indigenous men. Family unit and structure varied for participants. Some were full-time stay-at-home parents living with their children, or pregnant. Some lived by themselves, and others had roommates or lived with friends. Some individuals were married and living with their spouse or significant other (common-law, ex-fiancé). Intergenerational and kinship ties were also apparent: as one person noted, "I was living with my mom and grandson"; and another, "I was living with this same cousin". However, in some cases there was traffic in and out of the dwelling regardless of whether they were actual members of the household. For example, more transient situations included friends or family members who were "couch surfing", or ex-spouses who were co-parenting children and who would be in and out of the house.

Financial experiences ranged from a history of homelessness and unemployment to being in between jobs, unsteady work, or receiving income assistance. Most individuals described themselves as lowincome, financially supported through programs like the Saskatchewan Assured Income for Disability [SAID] program, or social assistance. A few mentioned they were balancing multiple roles (i.e. student and parent, or, student and working part time). Many interviewees identified health issues as impacting

53 David L Altheide \& John M Johnson, "Reflections on Interpretive Adequacy in Qualitative Research" in Norman K Denzin \& Yvonna S Lincoln, eds, The SAGE Handbook of Qualitative Research, 4th ed (Thousand Oaks, Cal: SAGE, 2011) 581 at 581. 
their ability to work and as impacting their ability to find and maintain housing. Others credited problems with their housing situations as directly causing health problems. ${ }^{54}$

Socioeconomic status and financial barriers were underlying issues in most if not all cases, and these issues became exacerbated by the process of the ORT hearing (i.e. having to pay for transportation or application fees). A few select quotes highlight some of the struggles that individuals faced:

- "I was receiving social service because I had cracked my wrist last fall. [...] I shouldn't have to explain my situation, people should be open minded, not to be judgmental, why I can't afford this and that." (Interview 7)

- "I got in an accident, so I no longer can cook...now I'm broke as a joke and homeless, I am homeless right now looking for a place." (Interview 1)

- "I was sick, literally getting to the point where, I was stressed out all the time, and I ended up in the hospital a lot." (Interview 23)

- "[T]he process then is deemed as, well you're the recipient [of social assistance], you're the problem, and because, being on social services is a huge factor in this, that you must have issues. And that's not, that's not so." (Interview 15)

\section{B. Housing and the significance of "home"}

The concept of "home" is complex and imbued with multiple meanings. Christensen's research about Indigenous homelessness in Canada showed that the meaning of home has to do with "positive, healthy relationships with family and friends, physical and mental health and well-being, strong cultural ties, personal safety, material security, independence, and self-determination." 55 However, physical homes that are safe, affordable, and secure matter deeply. For the respondents in Evelyn Peters and Carol Lafond's research about urban Indigenous youth in Saskatoon, home environments were the "safest and most comfortable places in which to practice their cultures and traditions." 56

Participants in our project echoed these themes, identifying that "home" is more than a roof and four walls and protection from the elements. For them, housing was closely tied to health, wellbeing, and security. One participant explained the importance of home as follows: "[i]t's your life! It's where you call home, it's where you unwind, it's where you raise your kids, it's where your family is, it's your comfortability, your safe zone - everything. It's your whole entire life. Not one little thing." 57

For some, better housing signalled a chance at a better way of life. For example, several participants noted a major transition from previous abuse of substances to living a "clean" life, which they wanted reflected in their housing situation. One participant said: "Because I am sick, so I need to find a home where I can feel safe, so I can, because I am sober now, I am straight. Before I use to drink a lot ..but now that I am straight and that I want to find a safe place, I don't want people around my house or anything

54 A body of research has shown the connections between poor housing conditions (including insecurity of tenure) and poor health outcomes. See Wellesley Institute, supra note 2; Toba Bryant, "The Current State of Housing in Canada as a Social Determinant of Health" (2003) Policy Options, online (pdf): <http://irpp.org/wp-content/uploads/assets/po/bankmergers/bryant.pdf>; Allyson E Gold, "No Home For Justice: How Eviction Perpetuates Health Inequity Among LowIncome and Minority Tenants" (2014) 24 Geo J on Poverty L \& Pol'y 59.

55 Christensen, supra note 32 at 168.

56 Evelyn Peters \& Carol Lafond, "II Basically Stick with my own Kind': First Nations Appropriation of Urban Space in Saskatoon, Saskatchewan" in Evelyn Peters \& Chris Anderson, eds, Indigenous in the City: Contemporary Identities and Cultural Innovation (Vancouver: UBC Press, 2013) 88 at 103.

57 Interview 1. 
anymore." ${ }^{58}$ Another stated: "these housing situations - this is where you live. This is going to determine your future of what your lifestyle is going to be." 59

Participants stressed that "home" means having control of who enters the space and privacy from landlords and neighbours. Appliances and amenities should be functional and accessible for operation. They noted that no one should have to live with pests, mold, improper heating, faulty windows, or other similar problems. Yet in many cases, these kinds of housing conditions were all too familiar. One participant stated of his former rental unit: "That was like the worst living situation I have ever lived in, just the feeling, I never felt that I was in my home." ${ }^{60}$ One participant, the mother of a young child, described her housing situation as follows: "I couldn't control the heat, and it was the winter time and I was cold all the time and I had to use my stove for a heater....my baby was getting sick a lot." ${ }^{\text {"61 }}$ Another participant said: "It is not a way that no one should have to live in Canada."

\section{The Claims}

The interviewees described a range of problems that brought them to the ORT. In almost every case, the tenant was responding to a landlord claim or action, most often a landlord claim for an order of possession of the unit. Indeed, of the 20 interviews we conducted, 16 tenants described eviction applications initiated by landlords. An additional three involved landlord claims for damages from the tenant (including claims for security deposits). Only one involved a claim initiated by the tenant. The reasons for landlord eviction applications varied. Most commonly, they had to do with non-payment or late payment of rent. One participant commented: "The nature of my housing problem was I was short on rent. Like continuously short on rent...my roommates kept stiffing me on rent... And they [the landlord] just had enough of it." ${ }^{63}$ Many tenants struggled with health conditions, lack of work, or childcare obligations, making it a struggle to pay the rent each month. One participant noted that the landlord sought to evict him after reneging on a "work for rent" arrangement: "he was supposed to give me credit for work with rent, never did. And made an application to the Rentalsman for a hearing based on rental arrears." ${ }^{\prime 64}$

Domestic violence was described as another root cause of evictions. In one case, a participant explained that her landlord had evicted her for non-payment after her abusive former fiancé assaulted her. She explained that her former fiancé had often refused to allow her to leave the apartment, stating "sometimes he wouldn't let me out and he told me he paid but he didn't." 65 She concluded: "I think they actually victimize the victim. The main reason that they were talking about evicting me was because they were saying that people were afraid that, well they were tired of hearing me be beaten and stabbed and yet they never called the police" ${ }^{66}$ Another participant noted that she and her common law partner were evicted "for fighting". ${ }^{67}$ These are examples of how domestic violence is connected to housing insecurity for women, and how residential tenancies law fails to adequately apprehend or address this problem. ${ }^{68}$

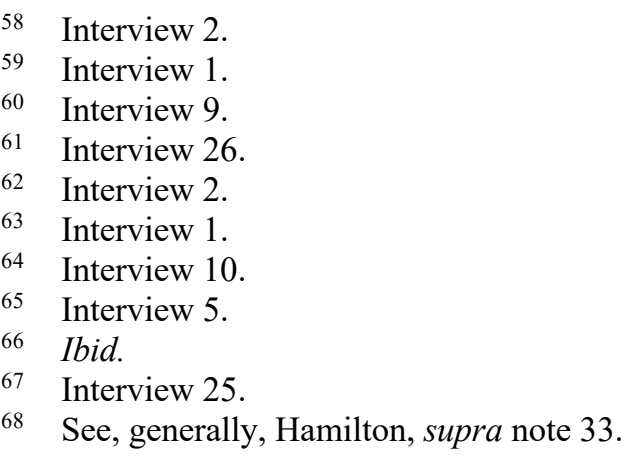


Several other female tenants noted that they were evicted after acts of violence or criminal involvement by partners or other people. One participant explained that she and her baby were evicted after the baby's father, who had gang affiliations, was the target of an attack on the house where "the front window was smashed, the door was kicked in." ${ }^{69}$ Another participant noted that after a break-in, she took the step of changing the locks to her unit which prompted an eviction application by the landlord. ${ }^{70}$ Men were also affected: one male participant noted that his landlord applied for an order of possession after other tenants in his building had an interaction with the police. He stated: "Even though nothing went down with the police. Like...it wasn't me that caused a problem, I never got charged or anything."

Several participants described evictions motivated by racism. One Indigenous woman, who was employed as a contractor, noted that she was evicted for drinking on weekends with friends, stating the landlord "didn't understand why we had money being First Nations people, being able to pay for rent and drink...He was pretty like racially profiling us, basically." "72 She noted that police investigated and found no wrongdoing, but the landlord proceeded nevertheless with an eviction application. "I was treated basically like another Indian" she commented. ${ }^{73}$ Another participant explained that her landlord accused her of drinking and partying, even though she does not touch alcohol. ${ }^{74}$ This participant also described language barriers she faced communicating with the landlord due to the fact that she was a Cree-speaker. Another tenant told us that people she knew faced eviction orders "[b]ecause of perceptions and it's just negative. They look at Native people as if you're the cause of all the grief." 75

One participant explained that her landlord applied for an order of possession after she withheld rent to protest the landlord's failure to address a bedbug infestation. ${ }^{76}$ Two participants noted that they were evicted because the landlord claimed that they wanted to complete renovations, all the while sensing that this was not the real reason for the eviction. ${ }^{77}$ Others described illegal lockouts by landlords, where they returned to their homes only to find that they had been locked out.

Only a few cases involved tenants making any sort of claim or counterclaim against their landlord. However, the narratives of the tenants reveal multiple apparent breaches of the Act by landlords: in almost all cases the tenants did not express awareness that these breaches could have formed the basis for a claim. In one example, an interviewee noted that the landlord had brought a claim for damages and cleaning after the end of the tenancy. This landlord had, during the tenancy, illegally entered the suite and harassed the tenant. She stated: "He walked in on me twice, once I was in the shower and once I was downstairs. He kept on being very bully, like being a man, like trying to bully me basically. Because I was a woman."78 Other narratives show clear breaches of the habitability standard required under the Act, for which tenants can make claims for breach of their tenants' rights. Tenants described housing conditions including lack of heating, pests, and broken appliances and plumbing: many explained that they had asked their landlord to fix the problems but without success. Although in most of the interviews it was unclear whether the

69 Interview 20

70 Interview 18.

71 Interview 9.

72 Interview 16.

73 Ibid.

74 Interview 8.

75 Interview 16.

76 Interview 24.

77 So called "renovictions" have been the subject of critique in Canada and beyond. Although the Act permits landlords to evict tenants in order to undertake renovations, concerns have been raised that landlords can use these kinds of provisions as pretexts to evict tenants. See, for example, British Columbia Rental Housing Task Force, supra note 24 at 8.

78 Interview 2. 
tenant articulated the problems with their housing conditions or landlord behaviours, it is quite clear that most hearing officers did not inquire into these matters, keeping them invisible in the hearing forum. ${ }^{79}$ Several tenants directly expressed that they had a lack of knowledge about their rights under the law. Having little to no awareness about their rights or how to assert them, along with fear of the landlord, functioned as barriers to their ability to initiate claims or counterclaims. In the words of a participant: "everything is just in general a strenuous situation. Not knowing what I'm going to do. Not knowing where I'm going to go. Not knowing my rights. Not knowing what the landlord has prepared for me." 80 Similarly, another participant felt "Frustrated, very frustrated, very lonely, very, I felt like not even paying my rent because what was the use? People that, you know, here I do pay my rent and I still can't even get things worked on, so frustrating, very frustrating." $" 81$

Overall, the tenant narratives reveal a picture of landlords who feel that they can get away with providing inadequate housing, and whose power to evict tenants is ever present. One tenant concluded that landlords "really like to push, push their weight around and know that they will get away with it basically...Because you get fed up with it and then you want to move." $" 82$

\section{Preparing to go to the ORT}

We asked tenants whether they attempted to negotiate a resolution with the landlord prior to the hearing. Some did engage in negotiation discussions, but in most cases tenants found it was futile or, in the words of one interviewee, "not an option." 83 The unwillingness of most landlords to negotiate illustrates the extent of landlord power in the relationship, and is perhaps indicative of the certainty that landlords feel about the vindication of their claims at the ORT. One participant stated, of negotiation: "I think I did at first and I even think my social worker tried because my social worker knows I'm very forthright and honest and that's all there is to it with me. And they still weren't willing to listen. ${ }^{84}$ Another noted: "She [the landlord] just didn't want that. She wanted all kinds of money from me." ${ }^{" 55}$ And another: "I tried to and no, he didn't hear anything we had to say. He just basically wanted us out no matter what." ${ }^{86}$ And another interviewee explained "Yes, we tried to discuss ways to resolve our problem and he wasn't forthcoming or wanting to take part in that, he just refused because...I don't know why. Maybe because he figured so positively that we were drug addicts or drug dealers or whatever." ${ }^{17}$ On the other hand, one tenant who had brought a claim against the landlord noted that she "didn't like the idea of being ignored but ..didn't really want to threaten [the landlord], so ... just went to the ORT, I didn't warn him I just did it." $" 88$

We also asked participants whether they had considered trying to get legal representation. Although the provincially funded Saskatchewan Legal Aid Commission does not assist with housing law in Saskatchewan, Community Legal Assistance Services for Saskatoon Inner City ("CLASSIC"), a free

\footnotetext{
79 This is somewhat reminiscent of Barbara Bezdek's observation, the context of her study of Baltimore's housing court, that tenants' concerns are often not treated as legal claims by housing court judges. Supra note 47 at 566.

80 Interview 1.

81 Interview 2.

82 Ibid.

83 Interview 22.

84 Interview 15.

85 Interview 11.

86 Interview 13.

87 Interview 16

88 Interview 8.
} 
community based legal clinic, does provide this kind of assistance in Saskatoon. ${ }^{89}$ However, most participants in our project had not heard of CLASSIC. One participant explained that she "contacted legal aid and they said they don't represent anyone for housing. And we phoned a few lawyers, but it was just too much. The cost was way too high." 90 However, some tenants did not look for legal assistance because they were unaware that legal representation was even an option. This appeared to be connected to a lack of understanding about the nature of the ORT itself as a legal forum, as demonstrated in the following quote: "When I went and filled out the paperwork for the process, um, nowhere in any of the paperwork, none of the staff told me this was a legal process and that therefore I could bring a lawyer with me. I thought that this was outside of court....But I found out after that this was considered court." 91 Another participant expressed a perception of a process that would produce a decision without input of the parties. She stated: "I just thought fricken just show up to court you know, get a slap on the wrist, and then either they decide if you're in or out. I didn't think like I needed a lawyer or nothing like that. So, like I didn't know we were eligible, like allowed or eligible for that." 92 Others explained that they were so overwhelmed and stressed about the situation that they did not have the ability to think about legal representation (i.e. "All my mind was on my family"93; "At the time I was just so distraught I didn't." While our interviewees did not turn to lawyers, many reported turning to social networks, friends, past experiences, and other sources of information, such as the internet, to help prepare for the hearing. One participant described the following scene: "People on the street, like in the morning, having coffee with someone, like Tim Hortons or whatever and talking about housing, people talking about housing." 95 Another recalled relying on "third hand information from people that have gone through the process." 96 Another participant who had previously had a hearing in another jurisdiction explained: "I have learned how to document things to do with the rental situation. So I applied all of that knowledge. I wasn't coached or taught by anyone else, it was previous experience." 97 Another participant said:

I went on Facebook and on Google and stuff and tried to find out, and that's how I know to, and my boyfriend said, "Take that paper, make sure". And my daughter wants to be a lawyer one day and she said, "take the list of things they do and things they are doing, things that are going on in here, make sure you take that paper. ${ }^{98}$

Another participant explained that she enlisted the help of a friend who could assist with translating words into Cree. She said: "This individual was explaining to me because my mother tongue is Cree, right? So some of the hard words I had to ask him about, you know? No big deal, but I like to learn words and that...I felt comfortable in the knowledge I was getting from him, I was starting to understand."99

Several participants described a process of reviewing and collecting documents and photographs, and making notes of dates and descriptions of various events. For example, one person noted: "I had a daily

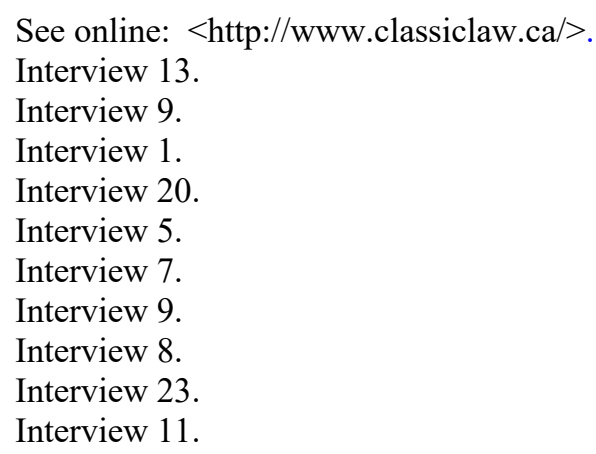


log of everything that I had done and the time, what tasks I had completed, what I had purchased, everything." 100 Another explained that she "Just wrote down all the times that I had interaction with him [the landlord]." 101 Yet another stated: "I had a notebook. Everything they said, I would write. Like they said I did cuts to the floor, I would write no, it was on the move-in form."102

We asked whether the staff at the ORT provided help: in most cases, tenants seemed unaware that they could receive information from the front desk staff. A few mentioned receiving and consulting a handbook about renters' rights and obligations from the ORT. Others reported that they did receive helpful information about the process from the front desk staff at the ORT. For example, one participant said: "they said it was like a court hearing, right? Two sides, one person on a side, the other person on the other side. We were not there to argue, we are just there to explain each side of the story, that prepared me."103 This participant continued: "They gave me information about what is going to happen and my rights, my part, why I am going there." 104 A couple of participants noted that they were discouraged by staff at the front desk who told them that there was nothing they could do in the face of the eviction being sought by their landlord. In another case "the receptionist at the Rental's board, um, right up told me that the Landlord was in the full right to do what they did and that I'm probably wasting my time going through the process". 105

Most participants expressed that the time leading up to the hearing was intensely stressful. The impact, particularly of eviction decisions, is hugely consequential and some were anticipating homelessness as a result. One participant said: "I was scared. I didn't want to be homeless."106 Another stated that she was "Totally freaked out, I was terrified, it had to do with my home, right?" 107 Others noted that they were exhausted, sick and frustrated leading up to the hearing. However, a few explained that they had not been too worried about the hearing before it happened, but reflected in retrospect that this sense of calm had been misplaced. One participant stated: "I was pretty good. I was ok. I didn't think I was going to get evicted and lose my damage deposit and all that bullshit." 108 Another added: "I was confident because I thought the entire thing was bogus. [...] I just didn't see how they had a right to charge me for a month rent after evicting me, not letting me in, ... So I thought I'd be fine. But yeah after, after the hearing, apparently like...it wasn't fine."109

While most interviewees described taking some steps to prepare for the hearing, a few noted that they did nothing to prepare in advance. For some this was because "life gets in the way", 110 or because they had no time to prepare, ${ }^{111}$ others explained that they were simply resigned to adverse outcomes. For example, one participant stated: "I didn't really do nothing because there was basically nothing I could do. Once I signed the rental agreement I knew the rental company, the option of having us vacated due to renovations and proper renovations and things like that. Which I should have read that in the first place." 112

\footnotetext{
100 Interview 10.

101 Interview 18.

102 Interview 21.

103 Interview 7.

104 Ibid.

105 Interview 9. Note that the previous name for the ORT was the "Rentalsman".

106 Interview 5.

107 Interview 8.

108 Interview 16.

109 Interview 9.

110 Interview 21.

111 Interview 27.

112 Interview 13
} 
For some participants, the inadequacy and instability of their housing created an additional barrier to properly being able to prepare for the hearing. When we asked one participant "Can you tell me a bit about what it was like preparing for the hearing, like what you did or anything like that?" He responded, "I just completed what my part was, being homeless in -30 degree weather, it is a big issue for somebody." This participant, who had been locked out of his home by the landlord, noted that given these circumstances, the main thing he could really do to prepare was to be "there on time." 113

\section{E. The Hearing}

Several themes emerged in participants' accounts about the hearing itself. Hugely consequential in participants' narratives was the hearing officer's actions and attitudes. Several respondents reported that hearing officers appeared to be biased in favour of the landlord from the outset, or to have made their decision even before the hearing started. A few identified that this bias seemed to be rooted in an apparent pre-existing relationship between the landlord and the hearing officer. One interviewee explained: "he [the hearing officer] had already made up his mind. He didn't even [write] anything down."114 This participant continued: "And the landlord yes ... it was like they knew each other too well and as soon as I walked in I knew." 115 Another participant explained: "There might be a relationship with the [ORT] and my landlords, which would have caused favouritism from the start, yeah. They seemed friendly. They were in there first, chatting, before I even got in there."116 And yet another noted that the landlord "apparently knows people in the Rentalsman hearing and she was trying to get them to be more or less on her side instead of my side. So be it, apparently she had a relative that was working there so I really don't know how to make of that." 117

Other tenants indicated that hearing officers tended to "believe" the testimony of landlords more than tenants due to the social and financial capital that accompanies property ownership, or simply due to racism. For example, one interviewee said:

Being a tenant, not having, not being actually listened to, or what I had to say isn't really considered as being truthful or honest or anything and as soon as the Landlord started opening his mouth, it was written in stone, everything he said was the truth and...cuz he owned the property and he's a good guy and the bank trusts him and everyone else trusts him and I was the tenant that has nothing. ${ }^{118}$

Another participant explained that the hearing officer "basically had his mind made up because he had all the pictures and all this in front of him, and I'm not sure if but it kind of felt like he was racist kind of towards me."119 This participant concluded: "The hearing officer was against me from the start." 120 Another participant explained that there was a difference between the concept of a "fair hearing" and what actually happens in a hearing. She stated "I understand what the process is to be, but that's not always what happens when you are there. And I find that, um, maddening and ignorant to the process because

\footnotetext{
113 Interview 7.

114 Interview 22.

115 Interview 23.

116 Interview 9.

117 Interview 11.

118 Interview 16.

119 Interview 22.

120 Ibid.
} 
it's a tribunal." She went on: "And that understanding and that magnitude. There's not a balance of power in that." 121

The hearing experience itself was also one where tenants experienced the exertion of landlord power. In most cases, landlords or their agents (building managers in the case of many corporate landlords) did not have counsel and so represented themselves at the hearing. Several interviewees noted that landlord agents behaved rudely or even belligerently during the hearing. Participants referred to attempts by landlords to attack their character, lie about events, and generally intimidate them. Landlords were heavily portrayed as money-seeking, and having little concern for the health and well-being of their tenants. One tenant noted: "They were just...he was trying to get the most money and arguing his case and it was just basically fraud or whatever." 122 Another stated: "the landlord went on the offensive and he was sort of saying, 'well, no, like she is wrong, but she is also like a terrible person'. Like it was sort of let's pull out other nasty things to say about her." 123 Likewise another participant said: "I was sick, I was disgusted with it. I couldn't believe they [the landlord] were allowed to just do that." 124 This tenant expressed that the most negative part of the hearings was "All of it. Just the way he [the landlord] was able to vacate us." 125 Another said: "I was pretty choked, I was angry. [...] Because the Landlord, he lied his ass off."126 Ultimately, most participants felt that their voice was not on equal standing with the landlord's, or that it was hard to remain calm and advocate for themselves in the face of this type of adverse experience. This identification by tenants of the ways that landlords exert power within the hearing process calls to mind the recent recommendations of the British Columbia Housing task force, which noted that renters identified that a fair hearing process meant preventing "a power imbalance between renters and rental housing providers". ${ }^{127}$

When we asked how they presented their case before the hearing officer, participants for the most part simply noted that they tried to explain their situation. Only one participant referenced the legislation or even their leases as informing their submissions in any way. One tenant, who had been evicted more than once due to inability to pay rent, took a matter of fact approach: "I just went. Listened to what they said. Told them I didn't have the rent money. I couldn't pay the rent money. So, pretty much out - shit out of luck. So I just left it at that". ${ }^{128}$ Another noted "I was glad to be telling my story, because they're trying to get me for $\$ 9000$, and it, and here I was living with cockroaches for the last month."129

For many, the process of testifying and advocating for oneself was highly stressful. Participants used words including "nervous", "overwhelmed", "worried", "disempowered", and "scared" when asked how they felt during the hearing. Several noted the challenges of genuinely "being heard" within the hearing context due to barriers including language, racism, education, and other factors. For example, one tenant explained "I have a hard time communicating because, it is very hard for me to speak to white people before of what I went through, hey? Prejudice and well, it is hard for me to speak." ${ }^{130}$ Another participant stated that she did not feel that the hearing was fair or that the hearing officer actually understood her. She explained that the hearing officer "went on [the landlord's] side because we didn't speak right, we didn't

121 Interview 15.

122 Interview 21.

123 Interview 8.

124 Interview 13.

125 Ibid.

126 Interview 16.

127 Interview 43.

128 Interview 1.

129 Interview 21.

130 Interview 11. 
have dates, we didn't have pictures...We didn't, I am not treaty, I am Metis, so it is hard for me.."131 Another interviewee, upon being asked "Did you feel like you were heard?" responded: "No. But by that point I was, personally, because the whole issue with the ex, and getting evicted, I was at a low point and, but I mean, generally, I roll with the punches." 132 This tenant, who was evicted after being assaulted by her former partner, noted that in the hearing she told the Hearing Officer "I was very, and I am, a quiet person, I go to the library and that is about it." For her, the hearing process was profoundly disempowering. She said:

I felt disempowered...Well, I mean, you go, and you tell the truth about things and events and you know you have made bad choices, in boyfriends, or...You think that someone will listen to you and they didn't, it was just like "you have got to move out."133

Conversely, a few participants explained that their experience of the hearing process was positive, mainly because the hearing officer took active steps to equalize power and "jump in" to stop bullying behaviour by landlords. It is notable that these participants expressed a sense of having been surprised when hearing officers expressed empathy, or took steps to make the process fairer. In other words, these experiences differed from what they were expecting. One participant explained: "the hearing officer would jump in. ...he helped me so much with what to say." 134 She noted that she was relieved that "justice was finally on my side for once." 135 Another expressed that she was pleasantly surprised that the hearing officer was "fair and whatnot." 136 Another identified that:

It was not one sided at all, like they hear every opinion of each side and they are very diligent about it, down to the detail - which I appreciate you know. Like I felt they were actually listening to what I had to say. Like how it needs to be done and my rights and everything - the rights and wrongs that the landlord was - in been treating me like that. So it was good. ${ }^{137}$

This person continued, "I felt like I was an equal person compared to the landlord." 138 She explained that the hearing officer stopped the landlord from "yelling" at her during the hearing. This was a situation where the tenant had already agreed to leave the rental unit: the hearing officer ordered that the tenant be permitted two weeks to move out. Another interviewee noted that she thought the process was "fair" insofar as the hearing officer required the landlord to follow procedure. "I think she was fair, putting it off until he did it properly, handed me the paper properly, she was fair about that." 139 A young mother noted that the Hearing Officer was "mad about it" when the tenant testified about her unit's lack of heating in the winter. ${ }^{140}$ But even in this case, the outcome was that the tenant had to move out. When asked "How

\footnotetext{
Interview 25.

Interview 5.

Ibid.

Interview 21.

Ibid.

Interview 2.

Interview 1.

Interview 1.

Interview 2.

140 Interview 26.
} 
did you feel about that ?" The tenant said, "I just, I just went about my day and I was like, "okay, I will move on then."141

\section{F. Reflecting on outcomes}

Participants noted that they found out about the outcome of the hearing either immediately following the hearing or shortly thereafter via registered letter. Decisions were typically in favour of landlords. In fact, landlords were successful in all cases involving eviction applications, although in several cases the tenants had already agreed to move out, leaving the ORT to consider issues such as returns of damage deposits. Typical quotes included:

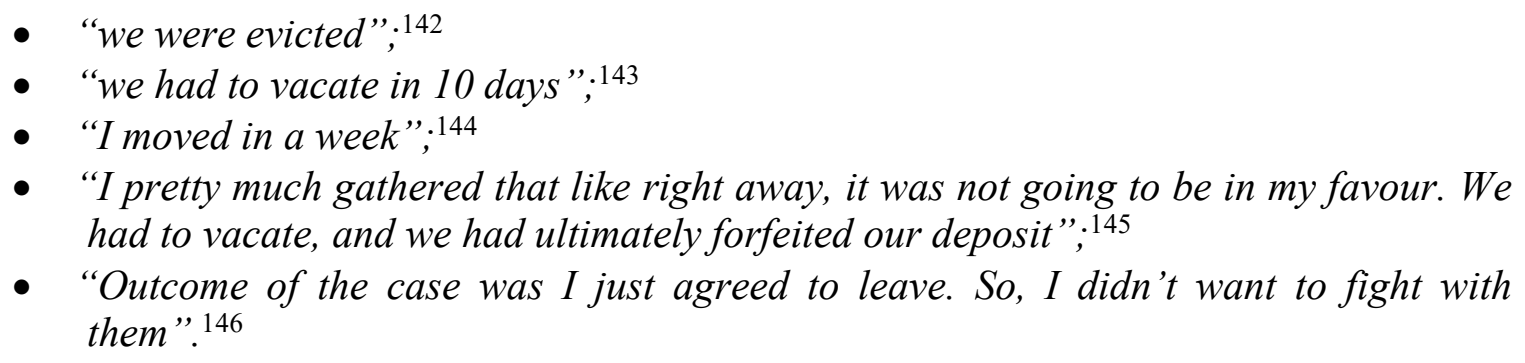

The outcomes underscore the way that the legislation and ORT process facilitates evictions of tenants who are poor and marginalized. Reasons for evictions included non or late-payment of rent, and claims by landlords that they planned to renovate the unit (note that these so-called "renovictions" have been identified as problematic pretexts for evictions of "undesirable" tenants). ${ }^{147}$ Evictions were also ordered in cases where tenants took actions to create a more secure or livable home for themselves: for example, by changing locks or withholding rent in an attempt to force a landlord to undertake repairs. As noted earlier, tenants were also evicted for behaviours of co-tenants or other building occupants. A tenant, who was evicted simply because of suspicion by the landlord about illegal activity, said that the hearing officer explained that "just because the police didn't find any actual evidence doesn't mean the evidence doesn't exist and we were given fourteen days I think - or twenty-one days? Twenty-one days to vacate."148

While landlords were successful in their eviction claims, there were a few cases where they were unsuccessful in their full claims for monetary damages against tenants. This was experienced as a huge relief by tenants who could ill afford to pay large judgments. One tenant expressed: "They didn't get away with taking me for $\$ 9000$, that they wanted someone to pay for renovation when I lived in a dump, it was all dumpy when I lived there."149 This tenant continued: "So in the end it was $\$ 1100$. And I was so proud of myself, I represented myself, you know, and I was so proud, because it was the truth. [...] I was happy. I wasn't happy that that happened. But I felt like, thank god, that they didn't believe them. You know. I

\footnotetext{
141 Ibid.

142 Interview 16.

143 Interview 13.

144 Interview 18.

145 Interview 13.

146 Interview 1.

147 See supra note 77.

148 Interview 16.

149 Interview 21.
} 
felt like justice was finally on my side for once." ${ }^{150}$ Another noted: "The outcome, it is still pending. But, I think he will be caught in his lies about how much be spent for like cleaning and what not."151

We asked participants about the longer term impacts of the ORT decision on their lives. Several noted that the decision led to ongoing housing precariousness and even homelessness. One participant explained: "I was really worried because I had nowhere to go and I am still homeless, and this was a year and a half now. I am homeless from the five year place I was staying." 152 Another interviewee, who also became homeless after she was evicted, disclosed that she contracted HIV as a result of being homeless, and identified HIV as the cost of the eviction. She said: "Can I say something...I got HIV from being homeless, I did, I did, and I blame it on being homeless. And I blame it on, I blame being homeless on the system." 153 Another participant stated: "I went from that living situation into a horrible roommate situation and then moved again like a month later." 154 Another noted that in the aftermath of the decision: "I felt awful, I cried for probably about a month because you know, you try and move in Saskatoon and it is expensive." 155

Participants also explained that the fallout from an eviction or negative relationship with a landlord could linger into the future and affect chances of securing future housing due to "background checks" by subsequent landlords. For example, one participant stated: "It just made it harder when we went to rent places later because that stuff comes up if they do like a...what is that called, a Rentalsmen check or whatever? Our names come up, they still come up in Rental...Rentalsmen background check or whatever ... they call it. [...] .. they ask me what sort of problems I've had, why have I been evicted from this place, that place." 156 Another stated: "It kind of gives me a little bit, I get kind of scared. I get kind of, you know, stage fright, because of the landlords knowing about my past." 157 The hearing process also served to jeopardize future relationships with the current landlord: one participant explained that while she was successful in her hearing outcome (related to a damages claim), the landlord retaliated a month later by evicting her. She said: "It really was a very onerous expensive process for something that really didn't deliver a lot of justice and then what the landlord did a month later, he was all worked up about, so I got this eviction notice on my door, no, nothing, like no, nothing else, no phone call, no nothing." 158

Overall, participants expressed that the ORT experience was negative and suggested that landlords were permitted to "get away" with lying, and exploitative behaviour. One tenant noted that the landlord, who evicted her after she had changed the locks following a break in, "got away with a lot." 159 Another participant said 'the process wasn't fair from beginning to end. It was one-sided, and we didn't matter either way. We were being thrown out no matter what. We weren't in rent arrears. We didn't owe any money..." 160 She summarized her feelings about the process as follows: "It is not fair. He who has the gold makes all the rules, determines who lives and who doesn't." ${ }^{161}$ Another tenant noted that "I learned that even if you do things the proper way sometimes you still, you know, have to move on." 162 Another noted that if the decision maker "would have heard more or listened maybe I would have been given time

150 Ibid.

151 Interview 2.

152 Interview 25.

153 Ibid.

154 Interview 9.

155 Interview 5.

156 Interview 16.

157 Interview 20.

158 Interview 8.

159 Interview 18.

160 Interview 13.

161 Ibid.

162 Interview 5. 
to pay the rent." 163 Finally, the tenant who was evicted after being assaulted by her fiancé, reflected that: "I think if they would have look at, I mean, I paid my rent, no one complained about me, I think that they probably should have let me stay."164

Despite the personal stress associated with going through the process, though, several participants explained that they were hopeful that their participation at the ORT would create a systemic impact beyond their individual outcomes. They expressed that a motivation for being involved in the ORT process was to hold exploitative landlords accountable for their abuses or educate them about the hardships faced by tenants. One tenant put it this way: "if more people do follow through with this maybe we can get something done with these slum landlords." 165 Another explained of the ORT hearing: "I got to put on record that the caretaker that was causing problems for me, he was on record with Rentalsman as, you know, someone who could be causing problems for future tenants." 166 Similarly, another participant suggested that the ORT could create a registry of problem landlords to help renters avoid bad situations. She said: "maybe Residential people could maybe black list them, or if they could make up a...website where people could go online and see the companies that are having these rat and mice problems." 167

Another stated that a positive outcome of the hearing was that the landlord would be "more educated about tenant people legally." 168 Yet another interviewee said that she would take what she had learned through the process into future relationships with landlords "so [landlords] can't get away with it because they have been." 169 Finally, one participant expressed that he was happy that we were undertaking this research, stating that he hoped that the research "acquires the teeth necessary to make sure that, you know, the Acts are enforced in a way and manner in which they are supposed and intended to be."170

\section{CONCLUSIONS}

The tenants who participated in our project drew a picture of a housing system where landlord power is extensive and sometimes exploitative. Their narratives also show that racism, sexism, and discrimination based on economic status and other factors influence the landlord-tenant relationship and the exercise by landlords of their power within the tenancy. It is within this larger context that landlordtenant legislation exists, and that housing law tribunals like the ORT operate. While official descriptions of the purpose of Saskatchewan landlord-tenant legislation and adjudication emphasize a notion of "balancing" of the interests of landlords and tenants, our interviews suggest a different story.

Indeed, our interviews suggest that for many tenants, the experience of a hearing at the ORT represented a continuation of unequal power relationships, where landlords appeared to have advantages due to a variety of factors including pre-existing relationships with hearing officers, their social status as property owners, or their ability to speak and navigate the language of advocacy and law. Many participants pointed to a situation where this unequal power was not constrained or mitigated in the hearing itself, and in fact was sometimes exacerbated. Many participants did not expect anything different. Perhaps, like the participants in Austin Sarat's research, they understood law as being "grounded in the

\footnotetext{
163 Interview 24.

164 Interview 5.

165 Interview 2.

166 Interview 5.

167 Interview 26.

168 Interview 7.

169 Interview 2.

170 Interview 10.
} 
realities of a society in which race, wealth, and power matter, and law is neither more nor less useful because it does not transcend or transform the world as they know it." ${ }^{171}$ It is significant that participants expressed surprise when hearing officers took active steps to prevent a landlord from engaging in bullying behaviour, or taking the time to listen carefully and understand the tenant's situation: this was not expected.

Although some tenants expressed confidence in their ability to represent themselves at the ORT, most stated that if given the opportunity, they would have preferred to have legal representation. One tenant said: "Getting a lawyer probably would have made it look more professional...get more of an idea of what my rights, and what rights I don't have and everything." 172 Another stated: "I think to have legal representation, that proves to a person that you're taking this seriously and that you want to resolve your issues but you also have the resources that will help you do that." 173 And another: "[lawyers] know the right words to use..."174 And finally: "Maybe, maybe they would have heard more or listened or maybe I would have been given time to pay the rent." 175 Given the power imbalances described above and the descriptions of our participants of the difficulty and stress of the hearing process, we believe that access to free legal assistance and representation for low income tenants is therefore essential. ${ }^{176}$

Despite the low expectations for their desired outcomes at the hearing, many participants had high hopes that their participation in the ORT process could help to instigate systemic change. They hoped for reforms that would hold exploitative landlords to account and that would ensure safer and more stable housing for tenants. They expressed a hope that decisionmakers would do more to fully consider the contexts of the landlord-tenant relationship and the struggles that tenants face. Many also expressed that these hopes were the motivation for answering our call to share their experiences. Given the centrality of a safe place to call home, and the devastating impacts of housing insecurity and evictions, we echo their insistence that a more just housing system is worth imagining, and working toward.

171 Austin Sarat, "The Law is All Over': Power, Resistance, and the Legal Consciousness of the Welfare Poor” (1990) 2 Yale JL \& Human 343 at 359.

172 Interview 1.

173 Interview 16.

174 Interview 2.

175 Interview 24.

176 See Sabbeth, supra note 15 for a comprehensive discussion of the importance and impact of representation for tenants. 